\title{
Ethnopharmacological and botanical evaluation of medicinal plants used by Brazilian Amazon Indian community
}

\author{
Avaliação etnofarmacológica e botânica de plantas medicinais utilizadas em \\ uma comunidade Indígena Amazônica Brasileira \\ Evaluación etnofarmacológica y botánica de plantas medicinales utilizadas por
la comunidad Indígena Amazónica Brasileña
}

Alexandre Zandonadi Meneguelli ${ }^{1}$

Ely Eduardo Saranz Camargo ${ }^{2}$

Danieli Fernanda Buccini ${ }^{3}$

Beatriz Cardoso Roriz ${ }^{4}$

Gabriela Ramos Cerqueira ${ }^{5}$

Susana Elisa Moreno ${ }^{6}$

Received on 02/07/2020; reviewed e approved on 05/07/2020; accepted on 05/07/2020.

DOI: http://dx.doi.org/10.20435/inter.v21i3.2926

\begin{abstract}
Plants have been widely used to treat many diseases, especially by traditional communities as Indians, that can be considered as an important source of empirical knowledge about the medicinal potential of the Brazilian biodiversity. This study aimed to investigate the use of medicinal plants by a particular AmazonIndian community named Ikólóéhj (Gavião). The data was obtained based on a semi-structured interview and long-term visits along the indigenous area to harvest the botanical material to subsequent identification and storage in herbarium. In the present work, we identify 23 plant species and three morphospecies, distributed into Ferns / Lycophytes and Angiosperms. In addition, we show that leaves (78\%), bark (13\%) and roots (9\%) were used via maceration (49\%), topical use (26\%), infusion and bath (13\%), and decoction (9\%). These plants were used to treat pain, diarrhea, malnutrition, parasites infection, wounds, and snakebites. We also observe that the knowledge about medicinal plants is shared to the older members of the community and this information is transmitted orally to the next generations. Thus, the present study contributes to the regrowth and preservation of knowledge about the use of medicinal plants providing important subsidies for understanding of therapeutic properties of Amazonian plants.
\end{abstract}

Keywords: Brazilian biodiversity; Amazon plants; traditional communities.

Resumo: As plantas têm sido amplamente utilizadas para tratar de muitas doenças, especialmente pelas comunidades tradicionais como índios, o que pode ser considerado uma importante fonte de conhecimento empírico sobre o potencial medicinal da biodiversidade brasileira. Este estudo teve como objetivo investigar o uso de plantas medicinais por uma comunidade indígena na Amazônia chamada Ikólóéhj (Gavião). Os dados foram obtidos com base em entrevistas semiestruturadas e visitas de longo prazo em toda a área indígena, a fim de coletar material botânico para posterior identificação e armazenamento em um herbário. No presente trabalho, identificamos 23 espécies de plantas e três morfoespécies, distribuídas em samambaias/licófitas e angiospermas. Além disso, mostramos que folhas (78\%), casca (13\%) e raízes (9\%) foram utilizadas para maceração (49\%), uso tópico (26\%), infusão e banho (13\%) e decocção (9\%). Essas plantas foram usadas para tratar dor, diarreia, desnutrição, infecções parasitárias, feridas e picadas de cobra. Também observamos que o conhecimento sobre plantas medicinais é compartilhado com os membros mais velhos da comunidade e que as informações são transmitidas oralmente para as próximas gerações. Assim, o presente estudo contribui para o crescimento e a preservação do conhecimento sobre

\footnotetext{
${ }^{1}$ Universidade Católica Dom Bosco (UCDB), Campo Grande, Mato Grosso do Sul and Faculdade Panamericana de Ji-Paraná (Unijipa), Ji-Paraná, Rondônia, Brazil.

2 Faculdade Panamericana de Ji-Paraná (Unijipa), Ji-Paraná, Rondônia, Brazil.

${ }^{3}$ Universidade Católica Dom Bosco (UCDB), Campo Grande, Mato Grosso do Sul, Brazil.

${ }^{4}$ Universidade Federal do Mato Grosso do Sul (UFMS), Campo Grande, Mato Grosso do Sul, Brazil.

${ }^{5}$ Instituto Nacional de Pesquisas da Amazônia (Inpa), Manaus, Amazonas, Brazil.

${ }^{6}$ Universidade Católica Dom Bosco (UCDB), Campo Grande, Mato Grosso do Sul, Brazil.
} 
o uso de plantas medicinais, fornecendo subsídios importantes para a compreensão das propriedades terapêuticas das plantas amazônicas.

Palavras-chave: biodiversidade brasileira; plantas amazônicas, comunidades tradicionais.

Resumen: Las plantas se han usado ampliamente para tratar de muchas enfermedades, especialmente por comunidades tradicionales como indígenas, que pueden considerarse una fuente importante de conocimiento empírico sobre el potencial medicinal de la biodiversidad brasileña. Este estudio tuvo como objetivo investigar el uso de plantas medicinales por una comunidad indígena en la Amazonía llamada Ikólóéhj (Gavião). Los datos se obtuvieron en base a entrevistas semiestructuradas y visitas a largo plazo en toda el área indígena para recolectar material botánico para su posterior identificación y almacenamiento en un herbario. En el presente trabajo, identificamos 23 especies de plantas y tres especies de morfo, distribuidas en helechos/ lycophytes y angiospermas. Además, demostramos que las hojas (78\%), la corteza (13\%) y las raíces (9\%) se usaron para maceración (49\%), uso tópico (26\%), infusión y baño (13\%) y decocción (9\%). Esas plantas se usaron para tratar el dolor, la diarrea, la desnutrición, las infecciones parasitarias, las heridas y las mordeduras de serpientes. También observamos que el conocimiento sobre las plantas medicinales se comparte con los miembros mayores de la comunidad y que la información se transmite oralmente a las próximas generaciones. Por lo tanto, este estudio contribuye al crecimiento y la preservación del conocimiento sobre el uso de plantas medicinales, proporcionando importantes subsidios para comprender las propiedades terapéuticas de las plantas amazónicas.

Palabras clave: biodiversidad brasileña; plantas amazónicas, comunidades tradicionales.

\section{INTRODUCTION}

The range of interactions between humans and plants dates back to antiquity and the use of natural resources was essential to guarantee the survival of civilizations. On this way, the development of humanity depended on the various forms of knowledge and use of plant resources, what were improved by the populations, determining both the landscape configuration and the characteristics of each culture (GANDOLFO; HANAZAKI, 2011; RANGEL, 2009).

Brazil has one of the highest rates of biological diversity in the world and is considered one of the highest cultural diversity countries, especially regarding the diversity of indigenous ethnicities, which are currently spread over 500 areas, inhabited by about 200 culturally different societies (DIEGUES, 2000).

Indigenous people are distributed by significant portion of the forests of the Amazon region, owning about 110 million hectares, corresponding to $12.5 \%$ of the Brazilian territory (CRISOSTOMO et al., 2015). According to data from Instituto Brasileiro de Geografia e Estatística (IBGE [Brazilian Institute of Geography and Statistics], 2012) in 2010, there were 896.9 thousand of Indians in Brazil, 36.2\% in urban areas and 63.8\% in rural areas. The total includes 817.9 thousand indigenous people, and also 78.9 thousand people who lived in indigenous lands and declared themselves of another color or race.

The Igarapé Lourdes indigenous territory, located in Ji-Paraná, Rondônia state, Brazil, has a territorial extension of 185,534 hectares, approved by Decree n. 88,609 of August 11, 1983, and is inhabited by Ikólóéhj and Karo indigenous ethnic groups (CARDOZO; VALE JUNIOR, 2012).

Situated in the Igarapé Lourdes indigenous territory, Cacoal community is occupied by Ikólóéhj ethnicity and consists of 13 families, in a total of 78 individuals. They are speaking TupiMondé and Portuguese languages, however, someone, especially older women and men, have difficulty speaking Portuguese (CARDOZO; VALE JUNIOR, 2012). Despite access to conventional medicine, the use of plants represents an important strategy to treating the most common diseases in the community. The knowledge about these medicinal plants is transmitted mainly orally to the next generations by the indigenous savant. 
Studies on the traditional use of plants in indigenous communities of Amazon are scarce, due to the difficulty of access to indigenous territories, limitations on the knowledge of the language of the different ethnic groups and the difficulty in formal identification of the plant species, which in many cases is only known in the communities by name in the native language.

In this context, this study aimed to conduct a survey on the medicinal plants used by Ikólóéhj (Gavião) ethnic group in the community of Cacoal, specifically on the indigenous land Igarapé Lourdes. It is expected that this work would help to elucidate the therapeutic indications and the ways of preparation of the medicinal plants more widely used by this community, as well as to compare the information obtained in our studies with data from the scientific literature.

\section{MATERIAL AND METHODS}

\subsection{Research Local}

The work was carried out at Igarapé Lourdes Indigenous Land, located in the Cacoal Community (Figure 1), with Ikólóéhj ethnic group that inhabits this area. The area is located approximately $58 \mathrm{~km}$ from the municipality of Ji-Paraná, in the state of Rondônia.

Figure 1 - Igarapé Lourdes Indigenous Land, located in the municipality of Ji-Paraná, state of Rondônia
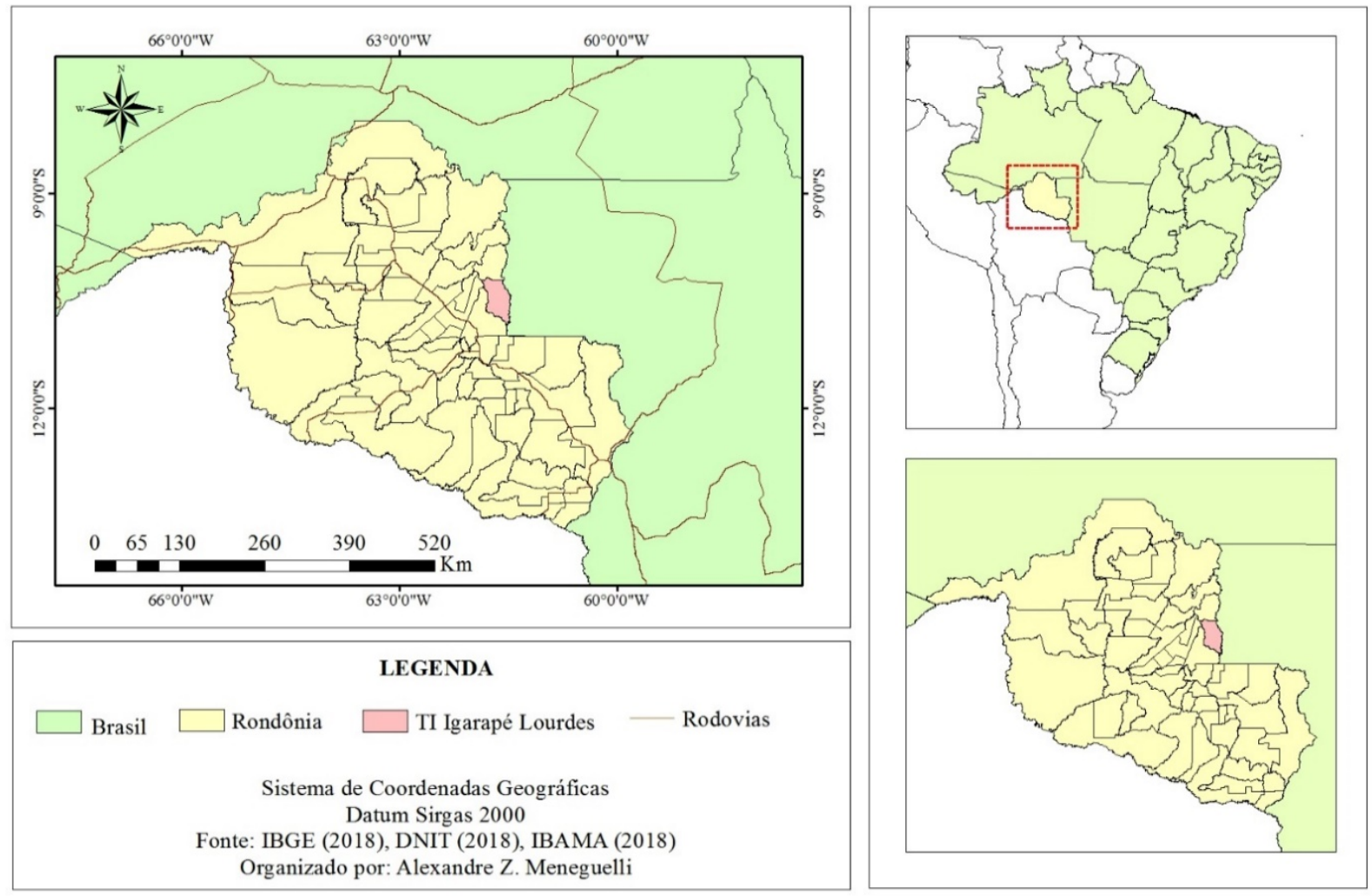

Source: IBGE (2018), DNIT (2018), IBAMA (2018), Organized by Alexandre Zandonadi Meneguelli.

\subsection{Authorizations}

All authorizations required to conduct the research were obtained as required by Normative Instruction 01 / Presidency of November 29, 1995 and Administrative Proceeding No. 
08620.142826 / 2015-44. The Indigenous Land Entry Authorization (number 7 / AAEP / PRES / 2018) was granted on January 22, 2018, effective from January 29, 2018 to June 20, 2020. The registration was also made with the National System of Management of Genetic Heritage and Associated Traditional Knowledge (SISGEN), in compliance with Law No. 13,123 / 2015 and its regulations (number A4B2495, December 27, 2017). The SISGEN registration number was also sent to the Fundação Nacional do Índio (FUNAI [National Indian Foundation]). As determined by Brazilian law, the project was submitted and approved by the Comissão Nacional de Ética em Pesquisa (CONEP [National Research Ethics Commission]), according to opinion number 2.356.262, of October 31st, 2017.

\subsection{Plant collection, identification and herborization}

To the ethnobotanical and pharmacological survey were used semi-structured interview (Supplementary Material), with information about local illnesses, herbal remedies, part of plant used, method of prepare, popular name in the indigenous language and therapeutic indications. Plant harvests were carried out in five, long-term visits along the indigenous area guided by the indigenous savant and an indigenous teacher responsible for translating the TupiMondé language into Portuguese. The plants indicated as medicinal were photographed and the botanical material collected to make exsiccates for later identification and deposit in the Herbarium Botanical Collection Dr. Ary Tupinambá Penna Pinheiro, from Centro Universitário São Lucas, Porto Velho, Rondônia, Brazil.

Plant species were identified according to standard taxonomic methods, based on floral morphological characters and analytical keys. The plant species were grouped into Families according to the classification system of the Brazilian Flora Species List (BFG, 2018). The samples were identified by the parataxonomist José Ramos of the Instituto Nacional de Pesquisas da Amazônia (INPA). Corrections to plant names in the indigenous language were made by indigenous professor José Palahv Gavião. For corrections to scientific names and families, a conference search was conducted on the official website of the Brazilian Flora Species List and the Missouri Botanical Garden.

The therapeutic uses of the plants by Gavião community were classified according the International Code of Diseases and Health Related Problems (ICD-10, 10th edition).

\section{RESULTS}

The investigation of plants with therapeutic application was conducted by guided tour, which consists in substantiating and validating the names of plants cited in interviews of the community members, using the method of species recognition by vernacular names indicated by the indigenous savant (ALBUQUERQUE; LUCENA; ALENCAR, 2010). It is important to highlight that the popular names may change according to the place and ethnicity consulted.

The ethnopharmacological research resulted in 23 plant species and 3 morphospecies with indications of medicinal use by the indigenous of Gavião community. These species are distributed into Ferns / Lycophytes and Angiosperms. Among the Angiosperms, the families identified were: Apocynaceae, Aracaceae, Bignociaceae, Celastraceae, Chrysobalanaceae, Connoraceae, Erythroxylaceae, Fabaceae, Icacinaceae, Malvaceae, Meliaceae, Menispermaceae, Moraceae, Piperaceae, Veraceae, Moraceae, Piperaceae. The botanical families, Celastraceae, Chrysobalanaceae and Menispermaceae stood out with two species mentioned as medicinal. 
Among the parts of the plants used for therapeutic purposes, the leaves were the most indicated (15 occurrences), followed by the fresh leaves (03 occurrences), the roots (03 occurrences), bark (02), stem (01), root peel (01) and potato (01) with only one indication. Regarding the ways of plants preparation, maceration was the most cited (17), followed by infusion (03), topical use (03) and decoction (02) and chewing (01).

The reports on the purpose of plant use were diverse, however, the use for the treatment of diseases related to digestive system disorders (diarrhea), endocrine diseases, nutrition and metabolism, injuries, poisonings and other consequences of external causes (wound healing), infectious and parasitic diseases (worms) were the most cited during the study.

Table 1 - Medicinal plants used in the Cacoal community

\begin{tabular}{|c|c|c|c|c|c|}
\hline \multirow[t]{2}{*}{$\begin{array}{l}\text { Herbarium } \\
\text { Registry }\end{array}$} & Family/Scientific Name & $\begin{array}{l}\text { Indigenous } \\
\text { name }\end{array}$ & $\begin{array}{l}\text { Part of } \\
\text { the plant }\end{array}$ & Preparation & Therapeutic use (CID-10) \\
\hline & HYMENOPHYLLACEAE & & & & \\
\hline \multirow[t]{2}{*}{7771} & Trichomanes pinnatum Hedw. & Goéhjsev & Leaf & Maceration & $\begin{array}{l}\text { Digestive System } \\
\text { Disorders }\end{array}$ \\
\hline & APOCYNACEAE & & & & \\
\hline \multirow[t]{2}{*}{7772} & $\begin{array}{l}\text { Geissospermum reticulatum } \\
\text { A.H.Gentry }\end{array}$ & Djíhn Sev & Leaf & Maceration & $\begin{array}{l}\text { Undefined conditions or } \\
\text { pains }\end{array}$ \\
\hline & ARACEAE & & & & \\
\hline \multirow[t]{2}{*}{7773} & $\begin{array}{l}\text { Monstera spruceana (Schott) } \\
\text { Engl. }\end{array}$ & Vazzer Va Sev & Leaf & Infusion & $\begin{array}{l}\text { Undefined conditions or } \\
\text { pains }\end{array}$ \\
\hline & BIGNONIACEAE & & & & \\
\hline \multirow[t]{2}{*}{7774} & $\begin{array}{l}\text { Fridericia nigrescens (Sandwith) } \\
\text { L. G. Lohmann }\end{array}$ & Vahjá Péuhn & Leaf & Maceration & $\begin{array}{l}\text { Endocrine, nutrition and } \\
\text { metabolism disorders }\end{array}$ \\
\hline & CELASTRACEAE & & & & \\
\hline 7775 & $\begin{array}{l}\text { Cheiloclinium cognatum (Miers) } \\
\text { A.C.Sm. }\end{array}$ & Aliádág & Stalk & Maceration & $\begin{array}{l}\text { Digestive System } \\
\text { Disorders }\end{array}$ \\
\hline \multirow[t]{2}{*}{$\mathrm{S} / \mathrm{N}$} & $\begin{array}{l}\text { Tontelea micrantha (Mart.) A.C. } \\
\text { Sm. }\end{array}$ & Aliadaàg póhj & Leaf & Maceration & $\begin{array}{l}\text { Digestive System } \\
\text { Disorders }\end{array}$ \\
\hline & CHRYSOBALANACEAE & & & & \\
\hline \multirow[t]{2}{*}{7776} & $\begin{array}{l}\text { Couepia bracteosa Benth. } \\
\text { *Parinari montana Aubl. }\end{array}$ & $\begin{array}{l}\text { Básev Abi } \\
\text { Kórkor } \\
\text { Basev Abi } \\
\text { Kórkor Sev }\end{array}$ & $\begin{array}{l}\text { Bark } \\
\text { Bark of } \\
\text { the Root }\end{array}$ & Maceration & $\begin{array}{l}\text { Digestive System } \\
\text { Disorders }\end{array}$ \\
\hline & CONNARACEAE & & & & \\
\hline \multirow[t]{2}{*}{7778} & Rourea camptoneura Radlk. & Boliria & Bark & Maceration & $\begin{array}{l}\text { Injury, poisoning and } \\
\text { other consequences of } \\
\text { external causes }\end{array}$ \\
\hline & ERYTHROXYLACEAE & & & & \\
\hline \multirow[t]{2}{*}{7779} & Erythroxylum macrophyllum Cav. & Maxah Kihr & Root & Maceration & $\begin{array}{l}\text { Infectious and parasitic } \\
\text { diseases }\end{array}$ \\
\hline & FABACEAE & & & & \\
\hline \multirow[t]{2}{*}{7780} & Vatairea sericea (Ducke) Ducke & Gérev Sev & $\begin{array}{l}\text { Leaf in } \\
\text { natura }\end{array}$ & Chewing & $\begin{array}{l}\text { Undefined conditions or } \\
\text { pains }\end{array}$ \\
\hline & ICACINACEAE & & & & \\
\hline \multirow[t]{2}{*}{7781} & $\begin{array}{l}\text { Casimirella ampla (Miers) } \\
\text { R.A.Howard }\end{array}$ & Babúgaá & Potato & Maceration & $\begin{array}{l}\text { Endocrine, nutrition and } \\
\text { metabolism disorders }\end{array}$ \\
\hline & MALVACEAE & & & & \\
\hline 7782 & $\begin{array}{l}\text { *Herrania mariae (Mart.) } \\
\text { Decne. ex Goudot }\end{array}$ & $\begin{array}{l}\text { Bajíhj Xóhgá } \\
\text { İhv }\end{array}$ & Leaf & Maceration & $\begin{array}{l}\text { Injury, poisoning and } \\
\text { other consequences of } \\
\text { external causes }\end{array}$ \\
\hline
\end{tabular}




\begin{tabular}{|c|c|c|c|c|c|}
\hline $\begin{array}{l}\text { Herbarium } \\
\text { Registry }\end{array}$ & Family/Scientific Name & $\begin{array}{l}\text { Indigenous } \\
\text { name }\end{array}$ & $\begin{array}{l}\text { Part of } \\
\text { the plant }\end{array}$ & Preparation & Therapeutic use (CID-10) \\
\hline & MELIACEAE & & & & \\
\hline \multirow[t]{2}{*}{7783} & *Trichilia catigua A.Juss. & Zaj Tapoh & $\begin{array}{l}\text { Leaf in } \\
\text { natura }\end{array}$ & Maceration & $\begin{array}{l}\text { Endocrine, nutrition and } \\
\text { metabolism disorders }\end{array}$ \\
\hline & MENISPERMACEAE & & & & \\
\hline 7784 & $\begin{array}{l}\text { Abuta sandwithiana Krukoff \& } \\
\text { Barneby }\end{array}$ & $\begin{array}{l}\text { Baséa Dov } \\
\text { Kav İhv }\end{array}$ & Bark & Maceration & $\begin{array}{l}\text { Skin and Subcutaneous } \\
\text { Cell Tissue Diseases }\end{array}$ \\
\hline \multirow[t]{2}{*}{7785} & $\begin{array}{l}\text { Anomospermum grandifolium } \\
\text { Eichler }\end{array}$ & $\begin{array}{c}\text { Pazá Tíh Vára } \\
\text { Sev }\end{array}$ & $\begin{array}{l}\text { Leaf in } \\
\text { natura }\end{array}$ & Maceration & $\begin{array}{l}\text { Digestive System } \\
\text { Disorders }\end{array}$ \\
\hline & MORACEAE & & & & \\
\hline \multirow[t]{2}{*}{7786} & $\begin{array}{l}\text { Brosimum lactescens (S.Moore) } \\
\text { C.C.Berg }\end{array}$ & Bóttih (Oiti) & Root & Infusion & $\begin{array}{l}\text { Endocrine, nutrition and } \\
\text { metabolism disorders }\end{array}$ \\
\hline & PIPERACEAE & & & & \\
\hline \multirow[t]{2}{*}{7787} & Piper plurinervosum Yunck. & Djoli Pehv Sev & Leaf & $\begin{array}{l}\text { Bath, Topic } \\
\text { use }\end{array}$ & $\begin{array}{l}\text { Diseases of the } \\
\text { musculoskeletal system } \\
\text { and connective tissue }\end{array}$ \\
\hline & QUIINACEAE & & & & \\
\hline \multirow[t]{2}{*}{7788} & Quiina amazonica A.C.Sm. & Gáh rúhv & Leaf & Decoction & $\begin{array}{l}\text { Infectious and parasitic } \\
\text { diseases }\end{array}$ \\
\hline & RHAMNACEAE & & & & \\
\hline \multirow[t]{2}{*}{7789} & Ampelozizyphus Ducke & ljó Sev & Leaf & Maceration & $\begin{array}{l}\text { Undefined conditions or } \\
\text { pains }\end{array}$ \\
\hline & RUBIACEAE & & & & \\
\hline \multirow[t]{2}{*}{7790} & Psychotria L. & Pekóa Sev & Leaf & Topic use & $\begin{array}{l}\text { Injury, poisoning and } \\
\text { other consequences of } \\
\text { external causes }\end{array}$ \\
\hline & RUTACEAE & & & & \\
\hline \multirow[t]{2}{*}{7791} & $\begin{array}{l}\text { Ticorea tubiflora (A.C.Sm.) } \\
\text { Gereau }\end{array}$ & $\begin{array}{l}\text { Ikoloehj Piaja } \\
\text { Sev }\end{array}$ & Leaf & Infusion & $\begin{array}{l}\text { Endocrine, nutrition and } \\
\text { metabolism disorders }\end{array}$ \\
\hline & SMILACACEAE & & & & \\
\hline \multirow[t]{2}{*}{7792} & Smilax rufescens Griseb. & Valutúg & Leaf & Chewing & $\begin{array}{l}\text { Endocrine, nutrition and } \\
\text { metabolism disorders }\end{array}$ \\
\hline & STEMONURACEAE & & & & \\
\hline \multirow[t]{2}{*}{7793} & Discophora Miers & Maxápo & Leaf & Maceration & $\begin{array}{l}\text { Infectious and parasitic } \\
\text { diseases }\end{array}$ \\
\hline & STYRACACEAE & & & & \\
\hline \multirow[t]{2}{*}{7794} & $\begin{array}{l}\text { *Styrax macrophyllus Schott ex } \\
\text { Pohl }\end{array}$ & Bosojá Sev & Leaf & Maceration & $\begin{array}{l}\text { Injury, poisoning and } \\
\text { other consequences of } \\
\text { external causes }\end{array}$ \\
\hline & VERBENACEAE & & & & \\
\hline 7795 & *Petrea volubilis L. & $\begin{array}{l}\text { ljahj Népo } \\
\text { Sága Sev }\end{array}$ & Leaf & Maceration & $\begin{array}{l}\text { Undefined conditions or } \\
\text { pains }\end{array}$ \\
\hline
\end{tabular}

Source: The authors.

The present study was the first, in the state of Rondônia, to register the occurrence of the following species: Herrania mariae (Mart.) Decne. ex Goudot, Parinari montana Aubl., Trichilia catigua A.Juss., Styrax macrophyllus Schott ex Pohl and Petrea volubilis L., according to the Brazilian Flora Species List ( BFG, 2018). 


\section{DISCUSSION}

Ethnobotanical studies investigate the relationship between traditional populations and plants, aiming at understanding other cultural discourses, their way of life, codes and customs (COTTON, 1996; ALBUQUERQUE, 2000). This gives ethnobotany great relevance to regional populations for the exploration and management of natural resources to obtain medicines, food and raw materials (FERRO, 2006). In the Cacoal community, where Ikólóéhj (Gavião) Indians inhabit, the plants are used in traditional medicine, as well as serving other purposes such as food, dyeing for body painting in traditional and religious festivities, dyeing for household utensils, handicrafts for personal use and marketing. Given the wide application of botanical resources by traditional communities, the present study carried out a survey of the most used species in the Cacoal community, with their respective therapeutic applications, the parts of the plant used and preparation. In addition, it was possible to formally identify the species evaluated.

The work resulted in 23 plant species and 3 morphospecies with indications of medicinal use by indigenous people. It is noteworthy that not all known plants were indicated by the indigenous savant, especially those with abortive properties, considering that sharing such knowledge could bring risks to the community.

Regarding the structure of the plant used for medicinal purposes, the leaves are the most indicated (70\%), but it was reported the use of bark, roots and stems. It is widely described that leaves are important sources of secondary metabolites with pharmacological activities, such as essential oils, sesquiterpene lactones, phenolic acids, flavonoids, coumarins, saponins, alkaloids, tannins, glucosinolates, cyanogenic glycosides, among others (GOBBO-NETO; LOPES, 2007).

Although the use of these plants in the Cacoal community occurs in an extractive manner, the reports presented by the indigenous savior, showing vast knowledge about the forms and periods of collection of botanical material, suggesting that the collection is made sustainably in order to minimize damage to species.

Although most indigenous communities in Brazil, currently, have access to allopathic medicines, the use of medicinal plants still occupies a prominent place in the treatment of the most common diseases in these populations. The knowledge and indication of medicinal plants are usually attributed to an older and more experienced member of the community, who, in the Cacoal community of the Ikólóéhj ethnic group, is called an indigenous savant. Beyond to his role in indicating plants for disease treatment, he is indispensable for the perpetuation of traditions through the transmission of knowledge to younger natives.

The reports on the purpose of plant use were diverse, however, they are used for the treatment of diseases related to digestive system disorders (diarrhea), endocrine diseases, malnutrition, injuries, poisonings and other consequences of external causes (wound healing), infectious and parasitic diseases (worms) were the most cited during the study.

Although the use of the reported plants is well established in the Cacoal community, researches on the therapeutic properties of these species are incipient or nonexistent. When comparing our data with the literature, we observed that the proposed medicinal use for plants by the indigenous savant in Cacoal community, in most cases, is not corroborated by the literature. As described in Table 1, among the 23 plant species and 03 morphospecies reported in our study, only for six of them (Trichomanes pinnatum Hedw, Geissospermum reticulatum AHGentry, Casimirella broad (Miers) RAHoward, Abuta sandwithiana Krukoff \& Barneby, Smilax rufescens 
Griseb and Petrea volubilis L.) have been found demonstrating their phytochemical characteristics and pharmacological properties. In some cases, other species of the genus mentioned in our study, occurring in other regions of Brazil or in other countries, had their properties evaluated, as shown for: Vatairea sericea, Monstera spruceana, Ampelozizyphus sp; Petrea volubilis; Vatairea macrocarpa, Fridericia nigrescens (Sandwith) L. G. Lohmann, Cheiloclinium cognatum (Miers) A.C.Sm, Tontelea micrantha (Mart.) A.C. Sm, Couepia bracteosa Benth, Rourea camptoneura Radlk, Erythroxylum macrophyllum Cav, Vatairea sericea (Ducke) Ducke, Trichilia catigua A.Juss. Anomospermum grandifolium Eichler, Brosimum lactescens (S.Moore) C.C.Berg, Piper plurinervosum Yunck, Quiina amazonica A.C.Sm, Ampelozizyphus Ducke, Psychotria L, Gereau, Smilax rufescens Griseb, Styrax macrophyllus Schott ex Pohl and Discophora Miers. Still, for other plants used for medicinal purposes in the Cacoal community, only the family was studied Herrania mariae (Mart.) Decne. ex Goudot and Ticorea tubiflora (A.C.Sm.).

Our results suggest that, although research on Brazilian biodiversity is expanding, there is still a large gap between traditional knowledge and scientific demonstrations of plant pharmacological properties. Also, when comparing the data obtained in this study regarding the therapeutic indication of plants in Cacoal community with the specialized literature, it was observed that in most cases the traditional use and scientific demonstrations are diverse, although some data may suggest the therapeutic effect of species in question.

In this context it was reported by the indigenous savant of the Cacoal community the use of various species (Vatairea sericea, Geissospermum reticulatu, Monstera spruceana, Ampelozizyphus sp. and Petrea volubilis) for the purpose of treating pain of various etiologies. Thus, Vatairea macrocarpa has been shown to have compounds capable of suppressing the synthesis of pro-inflammatory mediators (ALENCAR et al., 2006). Studies on the phytochemical and pharmacological properties of Geissospermum reticulatum have shown that extracts of this plant are provided with anti-tumor and antioxidant activity (SAJKOWSKA-KOZIELEWICZ et al., 2016). Regarding the genus Ampelozizyphus, it has been shown that the aqueous extract of A. amazonicus is immunomodulatory and anti-inflammatory (PEÇANCHA et al., 2013). Another strategy employed by the Cacoal community natives to treat pain is the leaves of Monstera spruceana, prepared by infusion. Although no studies showing the pharmacological effect of this species have been found, it has been shown that Philodendron bipinnatifidum of the Araceae family, which belongs to $M$. spruceana, has analgesic and anti-inflammatory activities related to the presence of flavonoids and phytosterols (SCAPINELLO et al., 2019).

Taken together, these data may constitute a scientific basis for the use of these species in Cacoal Community, as pain represents one of the cardinal signs of inflammation and antiinflammatory drugs are provided with analgesic action (SCAPINELLO et al., 2019).

The plant species Piper plurinervosum is indicated in Cacoal community for treatment of joint inflammation. This use may be related to the anti-inflammatory properties already demonstrated for many species of the Piper genus, which, due to their complex photochemical composition, they are used in the treatment of urological problems, skin, liver, stomach diseases, wound healing and as antipyretic agents. and anti-inflammatory drugs, as well as acting as natural antioxidants and antimicrobial agents (SALEHI et al., 2019).

Another frequent use of plants evidenced in our study in Cacoal community is as a source of nutrients, especially for children with signs of malnutrition. In this context, Fridericia nigrescens, Casimirella ampla and Ticorea tubiflora species were prepared by maceration or infusion. 
Corroborating the traditional use of Casimirella ampla, it has been shown by Ribeiro (2018) that the extract produced from the starch of Casimirella spp. has higher calcium, copper, iron, manganese and zinc concentrations than cassava and potato starch. For the other plants indicated for the purpose of mitigating malnutrition, the studies found do not correlate directly with these properties, but show that they are special with high therapeutic potential. Thus, Brandão et al. (2017) demonstrate that extracts of leaves, stems and fruits of Fridericia formosa have antiviral activity, being considered of interest for the development of new antiviral drugs. Regarding Ticorea tubiflora, there are no data on its pharmacological properties, however, Campelo et al. (2013) demonstrated species from the Rutaceae family, such as Citrus limon, were able to reduce urea, triglyceride and uric acid levels and improve renal function, probably due to the presence of monoterpenes.

In this study was showed that many plants are used to improve muscle strength and disposition in both adults and children. The species reported for this purpose were Trichilia catiguá and Smilax rufescens. In a research with Trichilia catigua, it was shown that the crude extract has analgesic, anti-inflammatory and neuroprotective effect (TRUITI et al., 2015). Although Smilax rufescens is little known, numerous pharmacological properties have been described for the genus Smilax, such as anti-inflammatory, analgesic, antioxidant, antimicrobial action, justifying its benefit in many clinical conditions.

In Cacoal community, diarrhea is highly prevalent, especially in children. In this condition the following species are employed for this purpose: Cheiloclinium cognatum, Tontelea micranta, Couepia bracteosa and Parinari montana. Cheiloclinium cognatum has been shown to have compounds such as tingenone and tingenol with activity against Entamoeba histolytica, Giardia lamblia, Trichomonas vaginalis and Trypanosoma cruzi (ROCA-MÉZQUITA et al., 2016), which could substantiate the effectiveness of its use in diarrhea, especially those caused by worms. However, on suspicion of worms, the treatment suggested by the indigenous savant in Cacoal community is made with macerated Erythroxylum macrophyllum and Discop/hora Miers. According to Macedo et al. (2016) Erythroxylum suberosum extract is provided with antitumor activity, but no references to antiparasitic action of the genus were found. For other species the studies show different effects from that attributed by the traditional knowledge of the indigenous people. Tontelea micranta has been described as rich in alkaloids, flavonoids, terpenoids and tannins, indicating its potential for prospecting new products of pharmaceutical interest (MERCADANTE-SIMÕES et al., 2014). Likewise, Couepia bracteosa has phenolic and carotenoid compounds with great potential for application to human health, especially against oxidative damage (BERTO et al., 2015). For the Parinari montana species, no data on their therapeutic properties were found, however, study with Parinari congensis demonstrated that the hydroalcoholic extract of leaves, stem and spikelet has activity against Plasmodium falciparum and Plasmodium berghei (LARYEA; BORQUAYE, 2019).

The use of plants to induce wound healing is also a common practice in Cacoal community, with Rourea camptoneura and Psychotria L. being indicated. Although this effect is not yet scientifically proven, it has been shown that the aqueous extract Rourea induta has analgesic action. related to the inhibition of release of inflammatory mediators (KALEGARI et al., 2014), which may correlate with their healing potential.

In addition to the diseases described above, numerous other conditions that affect the members of Cacoal community have been reported, such as snakebite accidents, for which Herrania mariae is employed. Similar to that observed with other plants reported in our study, no data corroborating this use were found, but according to data from Tian et al. (2019), in a 
study conducted with the Malvaceae family, the leaves of the species Abutilon theophrasti have compounds with anti-inflammatory action. Since in the snakebite accident, especially caused by Bothrops snakes, responsible for most cases of poisoning, the inflammatory response is responsible for the damage caused by the poison (JORGE et al., 2019).

\section{CONCLUSION}

The data of this study were obtained according to the highest values of importance concerning medicinal use of plants in Cacoal community, ensuring the great information about ethnobotanical profile of medicinal plants of this region. The preservation of culture and the practice of traditional medicine themselves represents important strategies for sustenance of indigenous culture, especially because the knowledge about medicinal plants is mainly restricted to the older members of the community and transmitted orally through to the next generations. Thus, the present study contributes to the regrowth and preservation of knowledge about medicinal plants in Cacoal Village, as well as, providing important subsidies for comprehension of therapeutic properties of Amazonian plants, supplying valuable information for support bioprospection of new drugs, since despite the largest biodiversity, few innovative products have been developed in Brazil from active constituents derived from the Brazilian biodiversity.

\section{ACKNOWLEDGMENT}

To all the indigenous people of the Cacoal Community, especially the indigenous savant Valtorino Gavião and the indigenous teacher José Palahv Gavião for their receptivity and teachings during the research period.

\section{FUNDING}

This study was supported by Coordenação de Aperfeiçoamento de Pessoal de Nível Superior (CAPES), Finance Code 001 (scholarship to Alexandre Zandonadi Meneguelli).

\section{REFERENCES}

ALBUQUERQUE, U. P. A etnobotânica no nordeste brasileiro. In: CAVALCANTI, T. B.; WALTER, B. M. T. (Org.). Tópicos atuais em botânica: Palestras Convidadas do 51으 Congresso Nacional de Botânica. Brasília: Embrapa Recursos Genéticos e Biotecnologia: Sociedade Botânica do Brasil, 2000. p. 241-9.

ALBUQUeRQUE, U. P.; LUCENA, R. F. P.; ALENCAR, N. L. Métodos e técnicas na pesquisa etnobiológica e etnoecológica. In: ALBUQUERQUE, U. P., LUCENA, R. F. P. (Ed.). Métodos e técnicas para coleta de dados etnobiológicos. Recife: NUPEEA: Livro Rápido, 2010.

ALENCAR, N. M. N.; ASSREUY, A. M.; HAVT, A.; BENEVIDES, R. G.; MOURA, T. R.; SOUSA, R. B.; RIBEIRO, R. A.; CUNHA, F. Q.; CAVADA, B. S. Vatairea macrocarpa (Leguminosae) lectin activates cultured macrophages to release chemotactic mediators. Naunyn Schmiedeberg's Archives Of Pharmacology, v. 374, n. 4, p. 275-82, Jan. 2006.

BERTO, A.; RIBEIRO, A. B.; SENTANDREU, E.; SOUZA, N. E; MERCADANTE, A. Z,; CHISTÉ, R. C.; FERNANDES, $E$. The seed of the Amazonian fruit Couepia bracteosa exhibits higher scavenging capacity against ROS and RNS than its shell and pulp extracts. Food \& Function, [s.I.], v. 6, n. 9, p. 3081-90, Sep. 2015. 
THE BRAZIL FLORA GROUP (BFG). Brazilian Flora 2020: innovation and collaboration to meet Target 1 of the Global Strategy for Plant Conservation (GSPC). Rodriguésia, v. 69, n. 4, p. 1513-27, 2018.

BRANDÃO, G. C.; KROON, E. G.; SOUZA FILHO, J.; OLIVEIRA, A. B. Antiviral activity of Fridericia formosa (Bureau) L. G. Lohmann (Bignoniaceae) extracts and constituents. Journal of Tropical Medicine, [s.I.], v. 2017, p. 1-11, 2017.

CAMPELO, L. M. L.; SÁ, C. G.; FEITOSA, C. M.; SOUSA, G. F.; FREITAS, R. M.. Constituintes químicos e estudos toxicológicos do óleo essencial extraído das folhas de Citrus limon Burn (Rutaceae). Revista Brasileira de Plantas Medicinais, Paulínia, v. 15, n. 4, supl. 1, p. 708-16, 2013.

CARDOZO, I. B.; VALE JUNIOR, I. C. Diagnóstico etnoambiental participativo, etnozoneamento e plano de gestão Terra Indígena Igarapé Lourdes. Porto Velho: Edufro, 2012. 9 2p.

COTTON, C. M. Ethnobotany: principles and applications. New York: J. Wiley, 1996. 320p.

CRISOSTOMO, A. C.; ALENCAR, A.; MESQUITA, I.; SILVA, I. C.; DOURADO, M. F.; MOUTINHO, P.; CONSTANTINO, P. A. L.; PIONTEKOWSKI, V. Terras indígenas na Amazônia brasileira: do orçamento à mitigação da mudança climática. Brasília, 2015. [Technical report].

DIEGUES, A. C. (Org.). Os saberes tradicionais e a biodiversidade no Brasil. São Paulo: Núcleo de Pesquisas Sobre Populações Humanas e Áreas Úmidas Brasileiras, Universidade de São Paulo, 2000. 211 p.

FERRO, D. Fitoterapia: conceitos clínicos. São Paulo, Atheneu, 2006. 502 p.

GANDOLFO, E. S.; HANAZAKI, N. Etnobotânica e urbanização: conhecimento e utilização de plantas de restinga pela comunidade nativa do distrito do Campeche (Florianópolis, SC). Acta Botanica Brasilica, Brasília, v. 25, n. 1, p. 168-77, 2011.

GOBBO NETO, L; LOPES, N. P. Plantas medicinais: fatores de influência no conteúdo de metabólitos secundários. Química Nova, Ribeirão Preto, SP, v. 30, n. 2, p. 374-81, Mar./Apr. 2007.

INSTITUTO BRASILEIRO DE GEOGRAFIA E ESTATÍSTICA (IBGE). Censo 2010: população indígena é de 896,9 mil, tem 305 etnias e fala 274 idiomas. Rio de Janeiro: IBGE, 2012.

JORGE, R. J. B.; MARTINS, R. D.; ARAÚJO, R. M.; SILVA, M. A.; MONTEIRO, H. S. A.; XIMENES, R. M. Plants and phytocompounds active against Bothrops venoms. Current Topics in Medicinal Chemistry, [s.l.], v. 19, n. 22, p. 1-10, 2019.

KALEGARI, M.; CERUTTI, M. L.; MACEDO JÚNIOR, S.; BOBINSKI, F.; MIGUEL, M. D.; EPARVIER, V.; SANTOS, A. R. S.; MIGUEL, O. G. Chemical composition and antinociceptive effect of aqueous extract from Rourea induta Planch. leaves in acute and chronic pain models. Journal of Ethnopharmacology, [s.I.], v. 153, p. 801-9, 2014.

LARYEA, M. K.; BORQUAYE, L. S. Antimalarial Efficacy and toxicological assessment of extracts of some ghanaian medicinal plants. Journal of Parasitology Research, [s.I.], v. 2019, p. 1-9, 2019.

MACEDO, T. B. C.; ELIAS, S. T.; TORRES, H. M.; YAMAMOTO-SILVA, F. P.; SILVEIRA, D.; MAGALHÃES, P. O.; LOFRANO-PORTO, A.; GUERRA, E. N. S.; SILVA, M. A. G. Cytotoxic Effect of Erythroxylum suberosum Combined with Radiotherapy in Head and Neck Cancer Cell Lines. Brazilian Dental Journal, Ribeirão Preto, v. 27, n. 1, p. 108-12, Jan./Feb. 2016. DOI: http://dx.doi.org/10.1590/0103-6440201600014 
MERCADANTE-SIMÕES, M. O.; SANTOS, H. C. M.; NERY, L. A.; FERREIRA, P. R. B.; RIBEIRO, L. M.; ROYO, V. A.; OLIVEIRA, D. A. Structure, histochemistry and phytochemical profile of the bark of the sobol and aerial stem of Tontelea micrantha (Celastraceae- Hippocrateoideae). Anais da Academia Brasileira de Ciências, v. 86, n. 3, p. 1167-79, 2014.

PEÇANHA, L. M. T.; et al. Immunobiologic and antiinflammatory properties of a bark extract from Ampelozizyphus amazonicus Ducke. BioMed Research International, [s.I.], v. 2013, p. 1-11, 2013.

RANGEL, M.; BRAGANÇA, F. C. R. Representações de gestantes sobre o uso de plantas medicinais. Revista Brasileira de Plantas Medicinais, Botucatu, SP, v. 11, n. 1, p. 100-9, 2009.

RIBEIRO, R. G. Estudo Etnobotânico e Físico-Químico da Batata-Mairá (Casimirella spp.- Icacinaceae). 2018. 126f. Dissertação (Mestrado em Botânica) - Instituto Nacional de Pesquisas da Amazônia (Inpa), Manaus, AM, 2018.

ROCA-MÉZQUITA, C.; GRANIEL-SABIDO, M.; MOO-PUC, R. E.; LEON-DÉNIZ, L. V.; GAMBOA-LEÓN, R.; ARJONA-RUIZ, C.; TUN-GARRIDO, J.; MIRÓN-LÓPEZ, G.; MENA-REJÓN, G. J. Antiprotozoal activity of extracts of Elaeodendron trichotomum (Celastraceae). Africa Journal of Traditional Complementary and Alternative Medicine, v. 13, n. 4, p. 162-5, July 2016.

SAJKOWSKA-KOZIELEWICZ, J. J.; KOZIELEWICZ, P.; BARNES, N. M.; WAWER, ı.; PARADOWSKA, K. Antioxidant, cytotoxic, and antiproliferative activities and total polyphenol contents of the extracts of Geissospermum reticulatum bark. Oxidative Medicine And Cellular Longevity, v. 2016, p. 1-8, 2016.

SALEHI, B.; ZAKARIA, Z. A.; GYAWALI, R.; IBRAHIM, S. A.; RAJKOVIC, J.; SHINWARI, Z. K.; KHAN, T.; SHARIFIRAD, J.d; OZLEYEN, A.; TURKDONMEZ, Elif; VALUSSI, M.; TUMER; T. B.; FIDALGO, L. M.; MARTORELL, M.; SETZER, W. N. Piper species: a comprehensive review on their phytochemistry, biological activities and applications. Molecules, [s.I.], v. 24, n. 7, p. 1-118, 2019.

SCAPINELLO, J.; MÜLLER, L.G.; SCHINDLER, M. S. Z.; ANZOLLIN, G. S.; SIEBEL, A. M.; BOLIGON, A. A.; NIERO, R.; SARAIVA, T. E. S.; MAUS, N. P.; BETTI, A. H.; OLIVEIRA, J. V.; MAGRO, J. D.; OLIVEIRA, D. Antinociceptive and anti-inflammatory activities of Philodendron bipinnatifidum Schott ex Endl (Araceae). Journal of Ethnopharmacology, v. 236, p. 21-30,May 2019.

TIAN, C.; CHEN, X.; CHANG, Y.; WANG, R.; NING, J.; CUI, C.; LIU, M. The regulatory effect of flavonoids extracted from Abutilon theophrasti leaves on gene expression in LPS-induced ALI mice via the NF-KB and MAPK signaling pathways. Pharmaceutical Biology, v. 57, n. 1, p. 514-8, Dec. 2019.

TRUITI, M. T.; SOARES, L.; LONGHINI, R.; MILANI, H.; NAKAMURA, C. V.; MELLO, J. C.; OLIVEIRA, R. M. Trichilia catigua ethyl-acetate fraction protects against cognitive impairments and hippocampal cell death induced by bilateral common carotid occlusion in mice. Journal of Ethnopharmacology, v. 172, p. 232-7, 2015.

\section{About the authors:}

Alexandre Zandonadi Meneguelli: Doctorate in Biotechnology, by the Universidade Católica Dom Bosco (UCDB). Master in Environmental Sciences, at the Universidade Federal de Rondônia (Unir). Specialist in Microbiology and Parasitology by the Faculdade Panamericana de Ji-Paraná (Unijipa). Graduated in Biological Sciences at the Centro Universitário Luterano de Ji-Paraná. College professor, coordinator of the Environmental and Sanitary Engineering course, coordinator of the Research Ethics Committee and coordinator of the Nucleus for Scientific Initiation and Extension of the Unijipa. Line of research: Health of the Traditional Populations of the Western Amazon. E-mail: meneguelli.azm@gmail.com, Orcid: https://orcid.org/0000-0003-3358-6151 
Ely Eduardo Saranz Camargo: Doctorate in Pharmacy by the Universidade Estadual Paulista Júlio de Mesquita Filho (Unesp), with a focus in Pharmacy. Master in Pharmaceutical Sciences by the Unesp, with a focus on Research and Development of Drugs and Medicines. Graduated in Pharmacy from the Universidade Metodista de Piracicaba. Is currently a professor at the Faculdade Panamericana de Ji-Paraná (Unijipa). Has experience in the following segments of Pharmacy: Development of Drugs and Medicines, Quality Control of Drugs and Medicines, Research and Development of Pharmaceutical Products and Cosmetics. In herbal medicine, has experience in Isolation and Identification of Organic Compounds, Pharmaceutical Assistance and Public Policies. E-mail: elycamargo@bol.com.br, Orcid: http://orcid.org/0000-0002-5215-2116

Danieli Fernanda Buccini: Post-doctoral student in Biotechnology at the Universidade Católica Dom Bosco (UCDB). Doctorate in Biotechnology and Biodiversity from the Federal University of Mato Grosso do Sul (UFMS). Master in Biotechnology at the UCDB. Graduated and bachelor in Biology from the Universidade Anhanguera-Uniderp. Member of the Animal Use Ethics Committee at the UCDB. Has experience in the fields of Pharmacology, with an emphasis on inflammatory, analgesic, and antimicrobial responses in vitro and in vivo models. E-mail: dfbuccini@gmail.com, Orcid: https://orcid.org/0000-0001-6381-3779

Beatriz Cardoso Roriz: Doctorate student in Biotecnology and Biodiversity at the Universidade Federal de Mato Grosso do Sul. Graduate in Biology at the Universidade Federal do Tocantins. E-mail: beatrizcroriz@gmail.com, Orcid: https://orcid.org/0000-0001-8585-1290

Gabriela Ramos Cerqueira: Doctorate student in Botany, at the Instituto Nacional de Pesquisas da Amazônia (Inpa). Master in Biological Sciences - Tropical Botany at the Museu Paraense Emílio Goeldi. Biologist graduated from the Universidade Federal de Rondônia (Unir).E-mail: gabiibio@ gmail.com, Orcid: https://orcid.org/0000-0001-9829-2088

Susana Elisa Moreno: Doctorate in Pharmacology from the Universidade de São Paulo (USP). Master in Pharmacology from the Universidade Estadual de Campinas (Unicamp). Graduated in Biology at the Pontifícia Universidade Católica de Campinas (PUC-Campinas). Professor and coordinator of the Graduate Program in Biotechnology at Universidade Católica Dom Bosco (UCDB). She also works in the Environmental Science and Agricultural Sustainability Programs (UCDB) and Doctorate in Network in Biotechnology and Biodiversity (UFMS). Chairman of the Comissão de Ética no Uso de Animais (Ceua). She works mainly in the field of Pharmacology, with projects aimed at prospecting compounds with anti-inflammatory, analgesic and healing action.

E-mail: smoreno@ucdb.br, Orcid: https://orcid.org/0000-0002-3715-5482

Note: The present work aims to evaluate the use of medicinal plants in the Gavião village, with a survey of the main plant species used therapeutically, and to compare this use with data available in the specialized literature. Therefore, it was necessary to set up a multidisciplinary research group to assess the different aspects of the work. Thus, professionals with knowledge in the fields of Botany, Pharmacology, and Phytochemistry also participated in the study, so that we could discuss the data collected more comprehensively. Contributions: Alexandre Zandonadi Meneguelli - student of the Doctoral Course in Biotechnology at the Universidade Católica Dom Bosco (UCDB); Ely Eduardo Saranz Camargo - co-supervising researcher, performed the survey of the pharmacological activities of the plants listed in the study, due to his experience in the area of Pharmacology and Medicinal Plants; Danieli Fernanda Buccini - performed the survey of the pharmacological activities of the plants listed in the study, due to her experience in the area of Pharmacology and Medicinal Plants; Beatriz Cardoso Roriz - acted in the survey of the pharmacological activities of the plants listed in the study, due to her experience in the area of Pharmacology and Medicinal Plants; Gabriela Ramos Cerqueira - assisted in the work of data collection in the field and in the process of formal identification of plant species, due to her experience in the area of Plant Systematics; Susana Elisa Moreno - guiding researcher. 
